\title{
Observation of bacteria over the surface of released oogonia from Fucus vesiculosus L. (Phaeophyceae)
}

\section{Observación de bacterias sobre la superficie de oogonios liberados de Fucus vesiculosus L. (Phaeophyceae)}

\author{
Franz Goecke ${ }^{1 \star}$, Antje Labes ${ }^{1}$, Jutta Wiese ${ }^{1}$, Rolf Schmaljohann ${ }^{1}$ \& Johannes F. Imhoff ${ }^{1}$ \\ ${ }^{1}$ Kieler Wirkstoff-Zentrum am GEOMAR, GEOMAR | Helmholtz-Zentrum für Ozeanforschung, Am Kiel-Kanal 44, Kiel D-24106, \\ Germany. \\ *fgoecke@geomar.de
}

\section{RESUMEN}

Pese al enorme número de bacterias que se encuentran normalmente en la columna de agua, se registra por primera vez su presencia sobre oogonios del alga Fucus vesiculosus. En cortes transversales, sin embargo, los oogonios se encontraban libres de epibiosis. Las algas fucoides son fundamentales en ciertos ambientes costeros, mas el impacto microbiano sobre su ciclo de vida y colonización es completamente desconocido.

\section{INTRODUCTION}

Bacteria are an inherent part of the physical environment of micro- and macroalgae (Hold et al. 2001). Many microorganisms have biofouling potential or interact with algae in pathogenic or non-pathogenic ways. Algae are especially susceptible to epibiosis being covered by diverse microbial communities (Goecke et al. 2010). Interactions between bacteria and algae are thought to be important in controlling the dynamics of both communities (Jasti et al. 2005). Although some of the macroalga-bacteria interactions have been discussed earlier, the ecological relevance of most naturally occurring bacterial communities on macroalgae remains unclear (Ivanova et al. 2002). In a study investigating the associations from bacteria with macroalgae in the Baltic Sea, we observed the distribution of microorganisms on the surface of Fucus vesiculosus Linnaeus 1753 (Fucales, Phaeophyceae) with scanning electron microscopy (SEM). Although bacteria are present by millions of individuals per millilitres seawater, this is the first observation of bacterial associations in the earlier stages of life of $F$. vesiculosus.

Fucus vesiculosus is a common intertidal and habitatforming alga widespread in Northern Hemisphere (Lüning 1990). As in most fucoids, it's reproductive tissue develops as receptacles, within which forms many spherical conceptacles containing antheridia and/or oogonia (male and female gametangia, respectively) (Pearson \& Serrao 2006). Inside a conceptacle, oogonia of all stages of development are placed between abundant hair-cell filaments (Fig. 1). A mature oogonium contains eight haploid eggs arranged in a characteristic manner (Naylor 1953). Structurally, the wall of oogonia in Fucus is composed of three layers, the exochite (thin outer-layer), mesochite (thick middle-layer), and endochite (thin inner-layer). When mature, the exochite ruptures, releasing the packet of eggs, still surrounded by two wall layers, which remain within the conceptacle (Naylor 1953, Lee 2008).

Gametes are released through the ostiole while still enclosed inside oogonia and antheridia. On contact with seawater, this egg packet increases in size and the oospheres round off, so that the eight chambered nature of the endochite can be clearly seen (Naylor 1953, Fig. 2). During their discharge from conceptacle a physical compression (of the oogonia) has been observed (Brawley et al. 1999). In seawater, the polysaccharide sheets that encase eggs and sperm dissolve rapidly to release them free. In antheridia, this occurs within a minute of discharge from the conceptacle, while eggs release can require ten minutes in calm culture dishes, but may rupture sooner in nature (Brawley et al. 1999). Eggs on release range in size from approximately $70 \mu \mathrm{m}$ in diameter. They are bounded only by a plasma membrane, but following fertilization there is a rapid secretion of a cell wall (Callow et al. 1978). Settlement directly follows release since fucoids lack a planktonic stage and have negatively buoyant eggs (Pearson \& Serrao 2006).

The present report is based on observations of one individual sampled in summer 2011 at Strande Beach, in the Kiel Fjord, Western Baltic Sea, Germany $\left(54^{\circ} 25.5^{\prime} \mathrm{N}\right.$, $\left.10^{\circ} 12^{\prime} \mathrm{E}\right)$ at two to six $\mathrm{m}$ depth. The samples were taken 
during a two years microbiological study (between 20082011) in which macroalgae were removed carefully from the substrate with a sissor and transferred into sterile plastic bags. Until processing within three hours after collection, the samples were stored in the dark at ambient seawater temperature using coolers. In the laboratory, the macroalgae were rinsed three times with sterile filtered Baltic Sea water to remove associated debris and loosely attached microorganisms. A voucher specimen weas deposited in the Herbarium of Museo de Historia Natural, Santiago, Chile (SGO). Samples were prepared for SEM by fixation with $1 \%$ formaldehyde in seawater. After dehydration in a gradient ethanol series $(30 \%, 50 \%, 70 \%, 90 \%$, and $100 \%$; v/ v) they were critical point dried with carbon dioxide (Balzers CPD030) and sputter coated with gold-palladium (Balzers Union SCD004). Specimens were examined in triplicate with a scanning electron microscope (Zeiss DSM960), and pictures were taken with a Contax SLR camera.

Under SEM, the surface of Fucus vesiculosus was shown to be covered by a diverse biofilm. In cross sections of conceptacles, oogonia still covered by exochite were apparently clean of epibiosis (Fig. 1). In one plant, at the ostiole area, a few oogonia already liberated from the exochite, where observed with bacteria on their surface (Fig.
2). Although bacterial 'contamination' has been mentioned previously in an experiment with eggs and embryos of Fucus vesiculosus (Peterson \& Torrey 1968), this is the first direct observation of bacteria over the surface of oogonia at the moment of their release from conceptacle (Fig. 2). If those bacteria play a role on algal ecology is completely unknown. The rupture of inner layers of oogonia for egg release has been described as a fast process driven by mechanical factors (Naylor 1953, Brawley et al. 1999), which does not seem to need external enzymatic degradation as some seeds in land plants (Howard \& Elliott 1988). Due an apparently smaller size of the oogonia (Fig. 2), bacterial degradation of unviable spores cannot be excluded. Bacterial biofilms can play a role in spore release, germination and subsequent colonization of substrates by algae (reviewed by Goecke et al. 2010). Macroorganisms can be expected to display the whole spectrum of host-bacterial associations on their surface, ranging from passive and random epibiosis to highly specific and obligate symbiosis (Bengtsson et al. 2011). Many of those bacteria can produce extracellular enzymes that enable them to utilize algal polysaccharide as carbon source (Ivanova et al. 2002). Although degradative and pathogenic effects of microbes on adult macroalgae have been already proved (Gachon et al. 2010), the

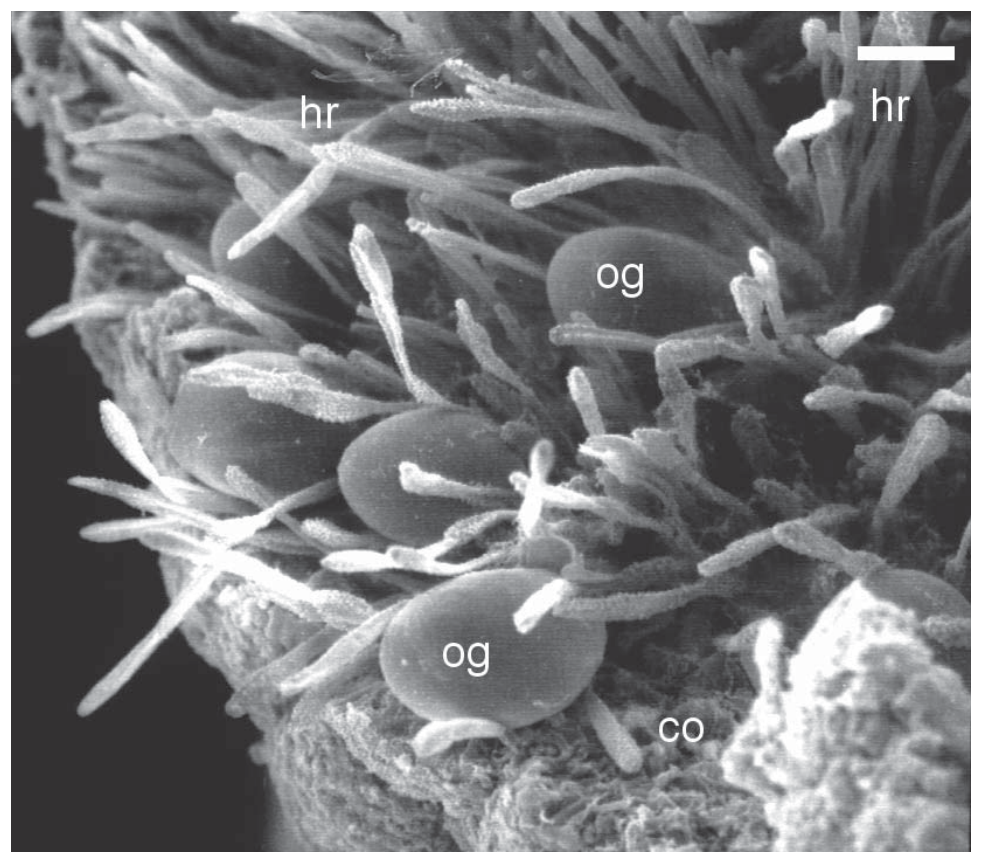

FIGURE 1. SEM microphotograph of a cross section of a single female conceptacle. Inside the conceptacle globular female oogonia (og) were placed between large number of hairs (hr) on the cortical cells of the plant (co) of the receptacle. Scale bar $=50 \mu \mathrm{m}$.

Figura 1. Microfotografía mediante microscopía electrónica de barrido del corte transversal de un conceptáculo femenino. Dentro del conceptáculo fueron observados diversos oogonios (og) de forma globular entre numerosos pelos (hr) sobre células corticales (co) del receptáculo. Escala $=50 \mu \mathrm{m}$. 
effect of bacteria over algal gametes and spores remain extremely neglected. The impact of microorganisms over life cycle and colonization process may be important factors regulating algal populations that should be investigated. Recent development of new detection and identification technologies is supporting the recognition of the role of parasites and diseases in food web dynamics and ecology of the aquatic environments (Neuhauser et al. 2011). Given the important role fucoids algae play in coastal environments as habitat-forming and base of food webs, we considered important to report this observation.

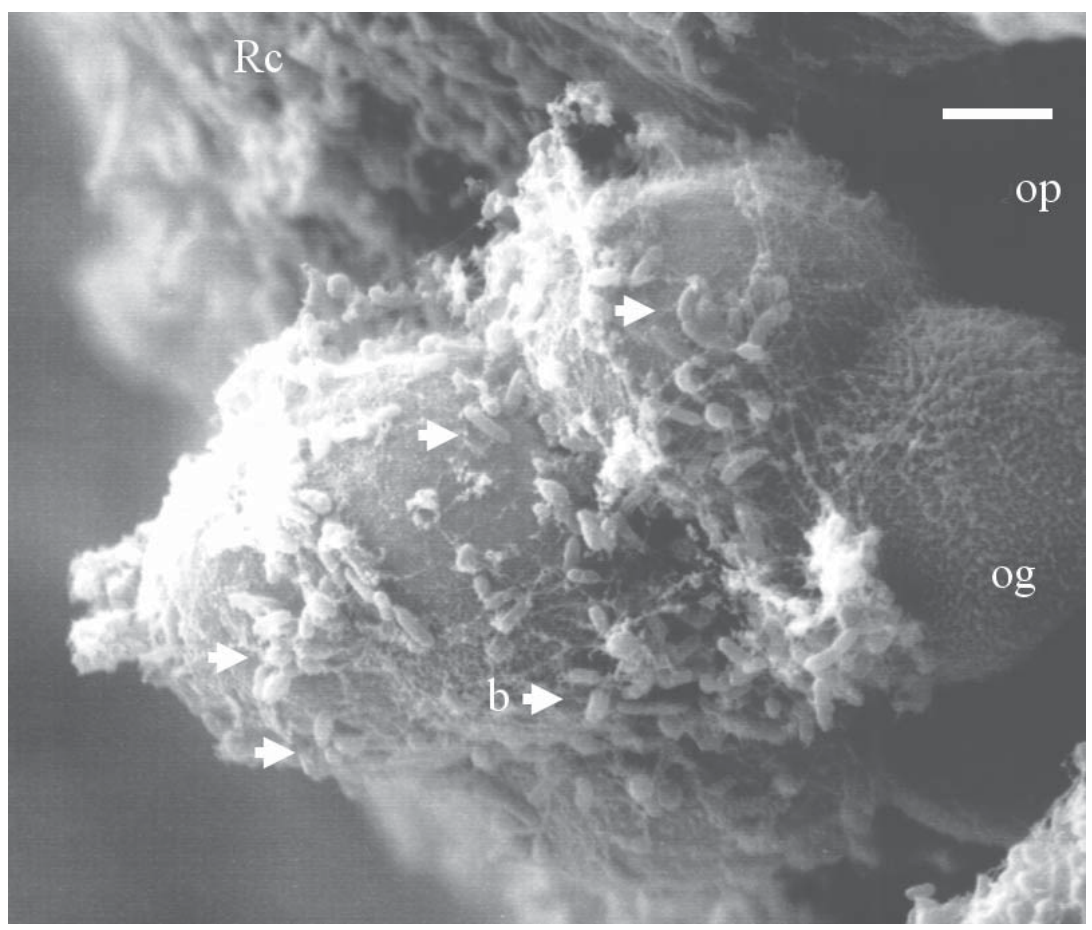

FIGURE 2. SEM microphotograph with the detail of an oogonium (og) previously liberated from its exochite and now being released of a conceptacle by the ostiole (op) of the receptacle (rc) in a reproductive Fucus vesiculosus. In the figure, six oospheres (of eight) of the oogonia are visible and already presented bacteria on the surface (arrows). Scale bar $=5 \mu \mathrm{m}$.

Figura 2. Microfotografía mediante microscopía electrónica de barrido con el detalle de un oogonio (og), previamente liberado de su exoquiton, abandonando el conceptáculo por el ostiolo (op) del receptáculo (rc) en una planta reproductiva de Fucus vesiculosus. En la figura, se observan seis de los ocho óvulos que conforman un oogonio y ya presentan bacterias asociadas a su superficie (flechas). Escala $=5 \mu \mathrm{m}$.

\section{ACKNOWLEDGMENTS}

This study was financed by the DAAD (German Academic Exchange Service) and CONICYT (Comisión Nacional de Investigación Científica y Tecnológica, Chile). We are grateful to the support given by the Kieler WirkstoffZentrum (KiWiZ) am GEOMAR, Germany. We are grateful to Dr. Juliet Brodie for critical comments in the article formulation.

\section{LITERATURE CITED}

Bengtsson, M.M., K. Sıøtun, J.E. Storesund \& L. Øvre̊̊s. 2011. Utilization of kelp-derived carbon sources by kelp surface- associated bacteria. Aquatic Microbial Ecology 62: 191199.

Brawley, S.H., L.E. Johnson, G.A. Pearson, V. Speransky, R. Li \& E. Serrao. 1999. Gamete release at low tide in Fucoid algae: Maladaptive or advantageous? American Zoologist 39: 218-229.

Callow, M.E., S.J. Coughlan \& L.V. Evans. 1978. Fertilization in brown algae. I. SEM and other observations on Fucus serratus. Journal of Cell Science 32: 45-54.

Gachon, C.M.M., T. Sime-Ngando, M. Strittmater, A. Chambouvet \& G.H. Kim. 2010. Algal diseases spotlight on a black box. Trends in Plant Science 15: 633-640.

Goecke F., Labes A., Wiese J., Imhoff J.F. 2010. Chemical interactions between marine macroalgae and bacteria. Marine Ecology Progress Series 409: 267-300.

Hold, G.L., E.A. Smith, M.S. Rappe, E.W. MaAs, E.R.B. 
Moore, C. Stroempl, J.R. Stephen, J.I. Prosser, T.H BirkBeCK \& S. Gallacher. 2001. Characterisation of bacterial communities associated with toxic and nontoxic dinoflagellates: Alexandrium spp. and Scrippsiella trochoidea. FEMS Microbiology Ecology 37: 161-173.

Howard, G.T. \& L.P. ElLIOTT. 1988. Effects of cellulolytic ruminal bacteria and of cell extracts on germination of Euonymus americanus L. seeds. Applied and Environmental Microbiology 54: 218-224.

Ivanova, E.P., I.Y. Bakunina, T. Sawabe, K. Hayashi, Y.V. AleXeeva, N.V. Zhukova, D.V. Nicolau, T.N. Zvaygintseva \& V.V. Mikhailov. 2002. Two species of culturable bacteria associated with degradation of brown algae Fucus evanescens. Microbial Ecology 43: 242-249.

Jasti, S., M.E. Sieracki, N.J. Poulton, M.W. Giewat \& J.N. RoONEY-VARGA. 2005. Phylogenetic diversity and specificity of bacteria closely associated with Alexandrium spp. and other phytoplankton. Applied and Environmental
Microbiology 71: 3483-3494.

Lee, R.E. 2008. Phycology. Cambridge University Press, USA. Fourth edition. 547 pp.

LÜNING, K. 1990. Seaweeds, their environment, biogeography, and ecophysiology. John Wiley \& Sons, New York, 544 pp.

NaYlor, M. 1953. The New Zealand species of Durvillaea. Transactions of the Royal Society of New Zealand 80: 277-297.

Neuhauser, S., M. Kirchmair \& F.H. Gleason. 2011. The ecological potentials of Phytomyxea ('plasmodiophoroids') in aquatic food webs. Hydrobiologia 659: 23-35.

Pearson, G.A.\&E.A. Serrao. 2006. Revisiting synchronous gamete release by fucoid algae in the intertidal zone: fertilization success and beyond? Integrative and Comparative Biology 46: 587-597.

Peterson, D.M. \& J.G. Torrey. 1968. Amino acid incorporation in developing Fucus embryos. Plant Physiology 43: 941947.

Recibido: 02.11.11

Aceptado: 10.05.12 